Інформація про авторів

PRAVDIUK Nataliia - Doctor of Economic Sciences, Professor, Head of the Department of Accounting, Vinnytsia National Agrarian University (21008, Vinnytsia, 3, Soniachna Str., e-mail: npravduyk@gmail.com).

BURKO Kateryna - Senior Lecturer of the Department of Accounting, Vinnytsia National Agrarian University (21008, Vinnytsia, 3, Soniachna Str., e-mail: k.burko@i.ua).

ПРАВДЮК Наталія Леонідівна - доктор економічних наук, професор, завідувачка кафедри бухгалтерського обліку, Вінницький національний аграрний університет $(21008$, м. Вінниця, вул. Сонячна, 3, e-mail: npravduyk@gmail.com).

БУРКО Катерина Володимирівна - старший викладач кафедри бухгалтерського обліку, Вінницький національний аграрний університет (21008, м. Вінниця, вул. Сонячна, 3, e-mail: k.burko@i.ua).

ПРАВДЮК Наталия Леонидовна - доктор экономических наук, профессор, заведующая кафедры бухгалтерского учета, Винницкий национальный аграрный университет (21008, г. Винница, ул. Солнечная, 3, e-mail:npravduyk@gmail.com).

БУРКО Екатерина Владимировна - старший преподаватель кафедры бухгалтерского учета, Винницкий национальный аграрный университет (21008, г. Винница, ул. Солнечная 3, e-mail: k.burko@i.ua).

УДК 640.4:006.015.5:005.336.3

DOI: 10.37128/2411-4413-2021-4-4

СТАНДАРТИЗАЦІЯ

І ОБГРУНТУВАННЯ

УПРАВЛІННЯ

ЯКІСТЮ

ПРОДУКЦІї ТА

ПОСЛУГ У

ГОТЕЛЬНО-

PECTOPAHНОМУ

ГОСПОДАРСТВІ
Д'ЯКОНОВА А.К., доктор технічних наук, професор кафедри готельно-ресторанного бізнесу

ТІТОМИР Л.А., кандидат технічних наук, доцент кафедри готельно-ресторанного бізнесу

ХАЛІЛОВА-ЧУВАСВА Ю.О., кандидат політологї̈, доцент кафедри готельно-ресторанного бізнесу

КОРОТИЧ О.М., стариий викладач кафедри готельно-ресторанного бізнесу, Одеський національний технологічний університет (м. Odeca)

Індустрія гостинності - це галузь економіки, яка швидко розвивається і сприяє розвитку інших галузей економіки країни. Розширюються культурні й ділові зв'язки Украӥни 
з іншими краӥнами, зростає кількість туристів, які потребують закладів розміщення $i$ сервісу, що відповідають міжнародним стандартам. Тому, останнім часом посилюється увага до якості, безпечності, конкурентоспроможності й стандартизації готельних послуг. Головним завданням підприємств індустрії гостинності є обслуговування гостей нашої краӥни, забезпечення їх місием проживання, організачія ділових зустрічей, задоволення попиту на якісний відпочинок і розваги.

У сфері гостинності широко використовують експертні методи дослідження якості наданих послуг, які базуються на застосуванні бальної шкали оцінювання якості. Для забезпечення якості послуг, щуо відповідають вимогам світових стандартів, необхідно введення відсутніх у країні єдиних законодавчих вимог, єдиних стандартів, єдиних процесів аналізу й перевірки якості продукиії та послуг, щуо надаються закладами готельноресторанного господарства. Використання кваліметричних методів оцінки дозволяє перевести якісні показники в кількісні, щчо полегшує прощес дослідження. Застосовано комплексний метод оцінки якості продукції і послуг, який полягає у вираженні оцінки рівня якості одним числом, отриманим в результаті об'єднання використаних одиничних показників якості в один комплексний показник.

У роботі досліджено якість послуг чотирьохзіркового готелю «Gagarinn» у місті Одеса. За анкетуванням визначено, шо критерієм якісного обслуговування є організація бронювання, прийому й розмімення в готелі. Встановлено, щзо гості закладу розміщення за груповими ознаками найбільше цінують професіоналізм і культуру обслуговування, потім зручність розрахунку й стандарт обслуговування. Комплексна оцінка якості обслуговування гостей в закладі розміщення становить 0,65. Отримані результати свідчать, щзо якість наданих послуг на етапі бронювання, прийому й розміщення гостей в дослідженому готелі відбувається на досить високому рівні.

Ключові слова: готельно-ресторанний бізнес, управління якістю послуг, кваліметрія, комплексний показник якості, оцінка роботи служб готелю, служба прийому й розміщення, служба бронювання.

Табл.: 3. Літ.: 13.

\title{
STANDARDISATION AND JUSTIFICATION OF PRODUCT AND SERVICE QUALITY MANAGEMENT IN THE HOTEL AND RESTAURANT INDUSTRY
}

\author{
DYAKONOVA Andzhela, \\ Doctor of Technical Sciences, Professor \\ of the Department of Hotel and Restaurant Business
}

TITOMYR Liudmyla, Candidate of Technical Sciences, Associate Professor of the Department of Hotel and Restaurant Business

KHALILOVA-CHUVAIEVA Yuliia, Candidate of Politology, Associate Professor of the Department of Hotel and Restaurant Business

KOROTYCH Olena, Senior Lecturer of the Department of Hotel and Restaurant Business, Odessa National Technological University 
The hospitality industry is a fast-growing sector of the economy, which contributes to the development of other sectors of the country's economy. Cultural and business relations of Ukraine with other countries are expanding, the number of tourists requiring accommodation and service facilities meeting international standards is growing. Therefore, attention to the quality, safety, competitiveness and standardisation of hotel services has recently increased. The main task of hospitality industry enterprises is to serve guests of our country providing them with accommodation, arranging business meetings, satisfying their demand for high-quality recreation and entertainment.

To study the quality of provided services expert methods based on a quality scoring scale are widely used in the field of hospitality. Unified legislative requirements, standards, quality analysis and verification of products and services provided by hospitality establishments is necessary to ensure the quality of services that meet the world standard requirements. Qualimetric assessment methods allow to convert qualitative indicators into quantitative ones, which simplifies the research process. To assess the quality of products and services a comprehensive method has been applied, which lies in the quality level assessment with a single number obtained by combining the used single qualitative indexes into one complex index.

The research is about the services quality of the four-star Gagarinn Hotel in the city of Odesa. The survey has revealed that the quality service criterion is well-organized booking, reception and accommodation of the hotel. It has been found that the guests accommodated by group characteristics value professionalism and service culture the most, followed by convenience of payment and service standard. The composite assessment of the guest service quality in the accommodation establishment is 0.65. The results show that the quality of services provided at the stage of booking, reception and accommodation of guests in the studied hotel is at a sufficiently high level.

Key words: hospitality business; service quality management; qualimetry; comprehensive quality indicator; evaluation of the hotel services; reception and accommodation service; booking service.

Tabl.: 3. Ref.: 13.

\title{
СТАНДАРТИЗАЦИЯ И ОБОСНОВАНИЕ УПРАВЛЕНИЯ КАЧЕСТВОМ ПРОДУКЦИИ И УСЛУГ В ГОСТИНИЧНО-РЕСТОРАННОМ ХОЗЯЙСТВЕ
}

\author{
ДЪЯКОНОВА А.К., \\ доктор технических наук, профессор \\ кафедры гостинично-ресторанного бизнеса
}

ТИТОМИР Л.А., кандидат технических наук, доцент кафедры гостинично-ресторанного бизнеса

ХАЛИЛОВА-ЧУВАЕВА Ю.А., кандидат политологии, доцент кафедры гостинично-ресторанного бизнеса

КОРОТЫЧ Е.Н., стариий преподаватель кафедры гостинично-ресторанного бизнеса, Одесский национальный технологический университет (2. Odecca) 
Индустрия гостеприимства - это быстроразвивающаяся отрасль экономики, которая способствует развитию других отраслей экономики страны. Расширяются культурные и деловые связи с другими странами, растёт количество туристов, нуждаюшихся в заведениях размещения и сервиса, отвечающих международным стандартам. Поэтому в последнее время усиливается внимание к качеству, безопасности, конкурентоспособности и стандартизачии гостиничных услуг. Главной задачей предприятий индустрии гостеприимства является обслуживание гостей нашей страны, обеспечение их местами проживания, организация деловых встреч, удовлетворение спроса на качественный отдых и развлечения.

В сфере гостеприимства широко используются экспертные методы исследования качества предоставляемых услуг, основанные на применении балльной шкаль оценки качества. Для обеспечения качества услуг, отвечающих требованиям мировых стандартов, необходимо введение отсутствующих в стране единых законодательных требований, единых стандартов, единых процессов анализа и проверки качества продукции и услуг, предоставляемых заведениями гостинично-ресторанного хозяйства. Использование квалиметрических методов оченки позволяет перевести качественные показатели в количественные, что упрощяает прочесс исследования. Применен комплексный метод оценки качества продукщии и услуг, заключающийся в выражении оченки уровня качества одним числом, полученным в результате объединения использованных единичных показателей качества в один комплексный показатель.

В работе исследовано качество услуг четырехзвездочной гостиниць «Gagarinn»в городе Одесса. По анкетированию определено, что критерием качественного обслуживания является организация бронирования, приема и размещения гостиниць. Установлено, что гости заведения по групповым признакам больще всего ценят профессионализм и культуру обслуживания, затем удобство расчета и стандарт обслуживания. Комплексная оценка качества обслуживания гостей в заведении размещения составляет 0,65. Полученные результаты свидетельствуют о том, что качество предоставляемых услуг на этапе бронирования, приема и размещения гостей в исследованном отеле происходит на достаточно высоком уровне.

Ключевые слова: гостинично-ресторанный бизнес, управление качеством услуг, квалиметрия, комплексный показатель качества, оценка работы служб гостиницы, служба приема и размещения, служба бронирования.

Табл.: 3. Лит.: 13.

Постановка проблеми. Готельно-ресторанний бізнес у структурі індустрії гостинності займає ключові позиції, тому що створює умови для розвитку туризму. Готельні послуги безпосередньо впливають на якість туристичних послуг і подальший розвиток туризму в нашій країні. Тому дуже важливо, щоб індустрія гостинності в Україні розвивалася у відповідності до вимог світових стандартів, що дозволить їй бути конкурентоспроможною як на внутрішньому, так i на міжнародному ринку туристичних послуг. Для забезпечення якості послуг, що відповідають вимогам світових стандартів, необхідно введення єдиних законодавчих вимог, стандартів, процесів аналізу й перевірки якості продукції та послуг у закладах готельноресторанного господарства. Тому, дотримання державних стандартів слід розглядати як критерій якості обслуговування в готельно-ресторанному бізнесі.

У сучасних умовах несприятливого економічного становища, на готельному ринку України спостерігається скорочення попиту на готельні 
послуги, що призводить до посилення конкуренції. Для підвищення конкурентоспроможності й залучення інвестицій, готелі намагаються поліпшити свій імідж і посилити привабливість засобів розміщення для гостей. Конкурентоспроможність готельних послуг значною мірою визначається їхньою якістю та безпекою, які гарантуються сучасними стандартами, впровадженням систем менеджменту якості й добровільною сертифікацією послуг закладів розміщення. У цьому відношенні якість готельних послуг відіграє важливу роль, тому що не тільки сприяє залученню туристів, але й є важливим фактором підвищення рейтингу засобів розміщення.

Світова практика розвитку готельного бізнесу свідчить, що визначальним фактором вибору гостем готелю і бажання скористатися його послугами $\epsilon$ висока якість наданих послуг. Якщо нового відвідувача закладу можна залучити яскравою рекламою або оригінальним інтер'єром приміщень, то другий раз він скористається послугами готелю тільки завдяки професійній роботі персоналу й високій якості обслуговування. Це потребує постійного вдосконалення якості готельних послуг за допомогою впровадження сучасних систем управління 3 використанням інноваційних технологій. Управління якістю послуг готельного підприємства повинно здійснюватися керівництвом закладу 3 використанням сучасних методів контролю якості послуг, що дозволить гарантувати високий рівень обслуговування, конкурентоспроможність і розвиток готельного бізнесу.

Аналіз останніх досліджень і публікацій. Проблемі забезпечення якості й конкурентоспроможності закладів готельного господарства, отримання об’єктивної оцінки функціонування закладів розміщення і визначення шляхів їхньої подальшої ефективної діяльності присвячено роботи значної кількості вітчизняних та іноземних фахівців готельно-ресторанної справи. Подлепіна П.О. здійснила аналіз методів оцінки конкурентоспроможності закладів готельного бізнесу й пропонує шляхи підвищення конкурентоспроможності підприємств готельної індустрії [1, с. 128]. У роботі Охоти B.I. [2, с. 46] розглянуто основні напрямки підвищення конкурентних переваг готельних підприємств України. Івченко Л.О. [3, с. 275] проаналізовано комплексні показники привабливості готелів, визначено номенклатуру одиничних показників i запропоновано метод кваліметричної оцінки привабливості готельних послуг. Сиволап Л.А. [4, с. 396] досліджено й розкрито ознаки конкурентоспроможності підприємства в сучасних умовах господарювання. Батченко Л.В. [5] проведено теоретико-методичний та практичний аналіз ринку готельних підприємств України для формування концептуального підходу до конкурентоспроможності готельних підприємств. Роботи іноземних авторів [6; 7, с. 301] присвячені дослідженню конкурентоспроможності й методології дослідження конкурентних позицій на ринку збуту товарів і послуг.

Аналіз робіт вітчизняних і закордонних авторів свідчить, що питання, які пов’язані 3 формуванням ринку готельно-ресторанних послуг i розвитком 
ринкових відносин, потребують об'єктивної оцінки якості продукції та послуг і визначення шляхів подальшого розвитку для забезпечення їхньої конкурентоспроможності. Тому, для ефективної діяльності закладів готельного господарства необхідно дослідити фактори, які суттєво впливають на якість готельних послуг і визначити шляхи підвищення конкурентоспроможності діючих закладів розміщення.

Формулювання цілей статті. Метою дослідження $\epsilon$ отримання об'єктивної оцінки діяльності закладів готельного господарства й розробка науково обгрунтованих рекомендацій 3 удосконалення системи управління якістю продукції та послуг підприємств готельного бізнесу для підвищення їхньої конкурентоспроможності на ринку готельних послуг.

Виклад основного матеріалу дослідження. У сучасних ринкових умовах, які характеризуються посиленням конкуренції, підприємства готельного бізнесу зацікавлені в тому, щоб сприйняття наданих послуг гостями закладів розміщення відповідало їхнім очікуванням. Створення системи якісного обслуговування на сьогодні є однією з важливих проблем готельного бізнесу. Система якісного обслуговування дуже важлива, тому що скорочення потоку туристів, у зв'язку з пандемією COVID-19, потребує переорієнтації діяльності готельного бізнесу на організацію і проведення з'їздів, конференцій, симпозіумів представниками великого й малого бізнесу, які $\epsilon$ більш вимогливими до якості послуг, потребують комфортного розміщення i створення умов для ділових зустрічей і плідної роботи. Основним завданням управління якістю в готельному бізнесі $є$ забезпечення стабільно високої якості послуг, оцінка яких пов'язана 3 певними складнощами. Готельні послуги, на відміну від продукції промислового виробництва, не можна перевірити заздалегідь. Вони характеризується нездатністю до збереження, мінливою якістю, невідчутністю, терміновістю, нерозривністю виробництва й споживання. Підприємство може тільки рекламувати переваги певної послуги, а саму послугу гість може оцінити тільки після того, як іiі отримає. Послуга формується в процесі обслуговування, під час взаємодії замовника й виконавця. Невідчутність і мінливість готельних послуг ускладнює їхню презентацію на ринку збуту і встановленню обгрунтованої ціни, яка повинна відповідати обсягу і якості наданих послуг. Тому, до ключових питань управління якістю належить необхідність зниження мінливості якості послуг. Для цього необхідно розробляти й впроваджувати стандарти, узгоджувати нормативи й вводити інструкції 3 надання готельних послуг. Надана послуга повинна формувати у гостя відчуття задоволення від якісного обслуговування.

Впровадження стандартів і нормативів на рівні підприємства є важливим елементом системи управління якістю, тому що вони спрямовані на забезпечення стабільно високої якості обслуговування. Нормативи й інструкції закріплюють виробничі обов'язки за окремими підрозділами й службами, посадовцями закладу розміщення, визначають порядок їхньої взаємодії, регламентують процес надання послуг. Стандартизація $\epsilon$ нормативним 
способом управління, яка має юридичну силу, i дозволяє гарантувати споживачам відповідність якості готельних послуг їхнім очікуванням. Управління якістю готельних послуг здійснюється на основі державних, міжнародних, галузевих стандартів і професійних інструкцій на підприємствах готельного бізнесу в залежності від категорії закладу [8].

Вимоги до якості послуг на міжнародному рівні визначені стандартами ISO cерії 9000, які встановлюють єдиний підхід до оцінки систем якості й одночасно регламентують відносини між виробниками й споживачами послуг. Вітчизняні стандарти визначають порядок і методи планування підвищення якості обслуговування на всіх етапах технологічного циклу виробництва продукції або надання послуг, встановлюють вимоги до засобів і методів контролю та оцінки якості обслуговування [8; 9]. Якість наданих послуг у готельному бізнесі повинна відповідати не тільки вимогам стандартів, але й потребам гостей закладів розміщення, які постійно змінюються. Такий підхід розкриває суть принципу орієнтації на споживача, задоволення потреб якого визначається співвідношенням очікуваних і реально отриманих якісних послуг.

Концептуальна модель забезпечення якості в готельному бізнесі базується на різних видах і стадіях діяльності з надання послуг, починаючи від визначення потреб гостей закладу до оцінки їхнього задоволення. Одним 3 основних методів підтвердження забезпечення якісних послуг, що надаються закладами готельного бізнесу, є сертифікація, яка суттєво впливає на взаємовідносини між працівниками й гостями закладів розміщення [10; 11]. Обов'язкова сертифікація готельних послуг у Системі УкрСЕПРО здійснюється на відповідність обов'язковим вимогам нормативних документів, чинних в Україні, щодо безпеки для життя та здоров'я людей, захисту їхнього майна й охорони навколишнього середовища. Споживачам це надає впевненості, що послуги надаються відповідно до встановлених стандартів, норм і правил. Вони оцінюють якість послуг у відповідності до задоволення своїх потреб i очікування. Крім того, наявність сертифікату на систему якісного обслуговування є однією з основних умов допуску готелю до участі у тендерах різних проєктів на вітчизняному й міжнародному ринку готельних послуг.

Якість готельних послуг залежить від багатьох факторів, до яких належать управління якістю обслуговування, матеріально-технічна база закладу, використання прогресивних технологій обслуговування. Якість обслуговування в готелях повинна відповідати вимогам, які базуються на забезпеченні очікуваного гостями рівня якості. Для цього потрібно знати, враховувати й навіть передбачати потреби гостей закладу, що дозволить зменшити вплив мінливості послуг на роботу закладу, забезпечити стабільно високу якість готельних послуг, вимоги до яких постійно підвищуються. Тому управління якістю варто розглядати не тільки як функцію вищого керівництва готельного бізнесу, а й як функціональну діяльність усіх організаційних структур і відділів підприємства, 
що спрямована на виявлення, попередження i задоволення очікувань споживачів готельних послуг.

Процес надання послуг гостям закладу починається вже 3 моменту звернення щодо бронювання номеру в готелі. Замовлення на бронювання можуть надходити у відділ бронювання або в службу прийому й розміщення за допомогою різних видів зв'язку (пошта, телефон або інтернет). Зустріч гостя може бути в аеропорту, на залізничному вокзалі або в готелі. Отже, операційний процес обслуговування гостя і його перші враження щодо роботи готелю починається із зустрічі, реєстрації, вручення ключа й супроводження до обраного номеру. В обов'язки відділу служби приймання i розміщення належить також оформлення остаточних розрахунків за проживання і додаткові послуги, оформлення виїзду гостя і надання різної інформації на запити тих, хто проживає у готелі.

До основних послуг, що надаються гостям готельного закладу належать такі: розміщення, харчування, сервісне й номерне обслуговування, а також додаткові послуги, а саме: перукарня, медпункт, фітнес-зал, SPA-салон, більярд та інші види сервісу, які надаються безпосередньо в готелі, а також сюди належать: замовлення транспорту, квитків на концерти, в театри, музеї, проведення екскурсій тощо.

Ефективне управління якістю послуг у готельному бізнесі $\epsilon$ найважливішим важелем забезпечення його прибутковості й конкурентоспроможності. Складність організації оцінки якості готельних послуг обумовлена необхідністю враховувати значну кількість внутрішніх факторів, пов'язаних із забезпеченням якісного обслуговування. Тому, заклади розміщення повинні не тільки виявити внутрішні фактори, що впливають на якість послуг, але й вивчити потреби споживачів для забезпечення найбільш повного їхнього задоволення. На якість обслуговування впливають фактори, що встановлені в нормативних документах і вимоги, які висувають безпосередньо гості закладів розміщення. До факторів впливу на якість обслуговування, які пов'язані 3 діяльністю готелю i забезпечують комфортність проживання, належать: якість системи управління, якість роботи служби приймання та розміщення, якість служби безпеки, якість харчування, якість обслуговування номерів, якість забезпечення технічними засобами, якість роботи електронних засобів, кількість і якість додаткових послуг тощо.

Отже, забезпечення якості обслуговування - це процес, який складається 3 певних етапів, від якості діяльності яких залежить рівень організації обслуговування гостей закладу загалом. Враховуючи важливість якості послуг у готельному бізнесі, їхній вплив на імідж, прибутковість i конкурентоспроможність закладів розміщення, для отримання об’єктивної оцінки якості обслуговування і визначення шляхів його покращення, необхідно вводити кількісні параметри показників якості. За комплексного підходу до оцінки якості обслуговування, необхідно охопити максимальну кількість складових, які формують якість обслуговування гостей на певному етапі 
роботи готелю. Необхідні дані для проведення розрахунків необхідно отримувати через моніторинг ступеня задоволеності споживачами якості наданих послуг за показниками, визначеними стандартом для закладів певної категорії, які формують основу сертифікації закладів розміщення.

Джерелом для аналізу оцінки задоволеності споживачами готельних послуг може бути анкетування, експертна оцінка, спостереження, інформація від персоналу готелю, книга скарг тощо. Найбільш ефективним способом збору інформації для оцінки задоволення гостей закладу $\epsilon$ анкетування, яке складається з кількох послідовних етапів: визначення переліку й критеріїв готельних послуг, що впливають на ступінь задоволення, розробка анкети, проведення анкетування для визначення ступеня задоволення послугами готелю, аналіз отриманих результатів дослідження. Об'єктом дослідження було вибрано чотирьохзірковий готель «Gagarinn» у м. Одеса, який у своїй інфраструктурі має 220 номерів різних категорій, ресторан «Food Hub», 9 конференц-залів, казино.

За результатами проведеного нами в он-лайн режимі анкетування, 168 гостей закладу надали свої відповіді та під час використання 5-ти бальної шкали оцінки якості було встановлено, що критерієм якісного обслуговуванням $\epsilon$ організація бронювання, приймання і розміщення. Такої думки дотримується $34 \%$ гостей закладу, 25\% - вважає критерієм якісного обслуговування сучасне електронне оснащення номеру, перевагу рівню безпеки віддають $18 \%$ споживачів, $13 \%$ - чистоті номеру, $10 \%$ - обслуговуванню в номері. Тому, найбільш важливим етапом роботи готелю, який суттєво впливає на оцінку якості обслуговування, $\epsilon$ перші враження гостя від процесу бронювання i розміщення. Споживач оцінює якість наданих послуг як ступінь задоволення його потреб й очікування.

Для оцінювання якості готельно-ресторанного продукту використовуються методи експертних оцінок на основі бальної шкали. Для полегшення процесу дослідження переводять якісні показники в кількісні, використовуючи кваліметричні методи. Метод кваліметрії складається 3 наступних послідовних операцій: визначення номенклатури одиничних показників оцінки якості i їхнього групування за категоріями, вибір кваліфікованих експертів, ранжування категорій, встановлення коефіцієнтів вагомості одиничних показників експертної оцінки послуг i розрахунку комплексного показника оцінки якості. Тому, експертами було розроблено анкету 3 переліком питань, що входять до стандартів обслуговування i безпосередньо впливають на відчуття гостя. Під час складання номенклатури показників оцінки якості обслуговування, на етапі бронювання і розміщення, було використано мінімальний перелік обов'язкових послуг для підприємств розміщення, який встановлений ДСТУ 4268:2003 [8]. Для отримання комплексної оцінки якості експертним методом використовуються різні середньозважені залежності, 3 яких найбільш широко використовується арифметична. 
Професором кафедри готельно-ресторанної справи Донецького національного університету економіки і торгівлі ім. М. Туган-Барановського Топольник В.Г. [12, с. 145] запропоновано метод розрахунку коефіцієнтів вагомості, зважаючи на конкретну інформацію щодо продукції або послуг, якість яких підлягає оцінці. Комплексний показник оцінки якості готельних послуг розраховується як сума добутків оцінки одиничних показників якості, помножена на коефіцієнт вагомості цього показника. У випадках, коли побудова функціональної залежності комплексного показника від вихідних даних має певні труднощі, комплексну оцінку отримують за допомогою різних середньозважених відносних показників 3 коефіцієнтами вагомості. За методикою Топольник В.Г [13, с. 108], показники якості послуг бронювання і розміщення в готелі доцільно групувати на три рівні. На кожному 3 них визначено групи показників, які поділяються на підгрупи, що формуються 3 одиничних показників (табл. 1).

Таблиия 1

\section{Структура показників якості служби приймання і розміщення в готелі}

\begin{tabular}{|c|c|c|c|}
\hline $\begin{array}{c}\text { Комплексні } \\
\text { показники } \\
\text { першого рівня }\end{array}$ & $\begin{array}{c}\text { Комплексні } \\
\text { показники } \\
\text { другого } \\
\text { рівня } \\
\end{array}$ & $\begin{array}{c}\text { Комплексні } \\
\text { показники } \\
\text { третього } \\
\text { рівня } \\
\end{array}$ & Одиничні показники комплексної оцінки \\
\hline \multirow{3}{*}{$\begin{array}{l}\text { Відповідність } \\
\text { цільовому } \\
\text { призначенню }\end{array}$} & \multirow{3}{*}{$\begin{array}{l}\text { Статус } \\
\text { гостя }\end{array}$} & \multirow{3}{*}{$\begin{array}{l}\text { Види оплати } \\
\text { за послуги }\end{array}$} & Оплата кредитною карткою \\
\hline & & & Оплата готівкою \\
\hline & & & Оплата через розрахунковий рахунок \\
\hline \multirow{8}{*}{$\begin{array}{l}\text { Дотримання } \\
\text { стандартів } \\
\text { обслуговування }\end{array}$} & \multirow{6}{*}{$\begin{array}{l}\text { Точність і } \\
\text { своєчасність } \\
\text { надання } \\
\text { послуг }\end{array}$} & & Тривалість перевірки наявності заявки на бронювання \\
\hline & & & Тривалість реєстрації \\
\hline & & & Тривалість ознайомлення гостя з правилами проживання \\
\hline & & & Тривалість очікування послуги портье \\
\hline & & & $\begin{array}{l}\text { Знайомство із сучасним електронним обладнанням у } \\
\text { номері }\end{array}$ \\
\hline & & & Знайомство з роботою зручностей у номері \\
\hline & \multirow{2}{*}{$\begin{array}{l}\text { Видача } \\
\text { ключа }\end{array}$} & & Електронний ключ-картка \\
\hline & & & Звичайний ключ \\
\hline \multirow{3}{*}{$\begin{array}{l}\text { Професіоналізм } \\
\text { персоналу }\end{array}$} & \multirow{3}{*}{$\begin{array}{l}\text { Професійні } \\
\text { якості }\end{array}$} & & Кваліфікація персоналу \\
\hline & & & Знання та виконання посадових інструкцій \\
\hline & & & Дотримання норм професійної етики \\
\hline
\end{tabular}

Джерело: складено авторами за даними [13, с. 109]

Наведена нами структура послуг етапу приймання і розміщення має чотири рівня. На нульовому рівні знаходиться комплексний (загальний) показник якості - К якості, на другому - комплексні підгрупові показники, які складаються 3 комплексних показників третього рівня, що об'єднують одиничні показники останнього четвертого рівня, які можна виміряти і оцінити. Завдання експертної оцінки полягає у створенні шкали порядку, роль якої виконує бальна шкала оцінок з трьома оціночними точками, тобто 3 непарною кількістю градацій (наприклад, 3 бали - послуга виконується відмінно у повному обсязі, 2 бали послуга виконується задовільно, але в основному правильно, 1 бал - послуга виконується з великою кількістю порушень). Характеристику показників якості процесу бронювання і розміщення та їхньої значимості по бальній шкалі наведено в таблиці 2. 


\section{Бальна оцінка показників якості процесу надання послуг з бронювання та} розміщення в готелі

\begin{tabular}{|c|c|c|c|}
\hline \multirow{2}{*}{$\begin{array}{l}\text { Одиничні показники, що } \\
\text { оцінюються }\end{array}$} & \multicolumn{3}{|c|}{ Характеристика показників якості за кількістю балів, бали } \\
\hline & 3 & 2 & 1 \\
\hline $\begin{array}{l}\text { Оплата кредитною } \\
\text { карткою }\end{array}$ & $\begin{array}{l}\text { Оплата кредитною } \\
\text { карткою за всі види } \\
\text { послуг }\end{array}$ & $\begin{array}{l}\text { Оплата кредитною } \\
\text { карткою тільки за окремі } \\
\text { послуги }\end{array}$ & $\begin{array}{l}\text { Оплата кредитною } \\
\text { карткою відсутня }\end{array}$ \\
\hline Оплата готівкою & $\begin{array}{l}\text { Оплата готівкою у різній } \\
\text { валюті }\end{array}$ & $\begin{array}{l}\text { Оплата готівкою у гривнях } \\
\text { (можливий обмін валют) }\end{array}$ & $\begin{array}{l}\text { Оплата готівкою тільки у } \\
\text { гривнях }\end{array}$ \\
\hline $\begin{array}{l}\text { Оплата через } \\
\text { розрахунковий рахунок }\end{array}$ & $\begin{array}{l}\text { Оплата через } \\
\text { розрахунковий рахунок } \\
\text { за всі види послуг }\end{array}$ & $\begin{array}{l}\text { Оплата через } \\
\text { розрахунковий рахунок } \\
\text { тільки окремих послуг }\end{array}$ & $\begin{array}{l}\text { Оплата через } \\
\text { розрахунковий рахунок } \\
\text { відсутня }\end{array}$ \\
\hline $\begin{array}{l}\text { Тривалість перевірки } \\
\text { наявності заявки на } \\
\text { бронювання }\end{array}$ & $\begin{array}{l}\text { Пошук заявки не } \\
\text { перевищує } 2 \text { хв }\end{array}$ & $\begin{array}{l}\text { Пошук заявки займає } \\
\text { більше } 3 \text { хв }\end{array}$ & $\begin{array}{l}\text { Пошук заявки перевищує } \\
5 \text { хв }\end{array}$ \\
\hline Тривалість реєстрації & $\begin{array}{l}\text { Реєстрація не перевищує } \\
10 \text { хв }\end{array}$ & $\begin{array}{l}\text { Тривалість реєстрації - } \\
10 \text { хв }\end{array}$ & $\begin{array}{l}\text { Реєстрація перевищує } \\
10 \text { хв }\end{array}$ \\
\hline $\begin{array}{l}\text { Тривалість ознайомлення } \\
\text { гостя з правилами } \\
\text { проживання }\end{array}$ & $\begin{array}{l}\text { Ознайомлення } 3 \\
\text { правилами протягом } 1 \text { хв }\end{array}$ & $\begin{array}{l}\text { Ознайомлення } 3 \\
\text { правилами протягом } 3 \text { хв }\end{array}$ & $\begin{array}{l}\text { Ознайомлення } 3 \\
\text { правилами протягом } 5 \text { хв }\end{array}$ \\
\hline $\begin{array}{l}\text { Тривалість очікування } \\
\text { послуги портьє }\end{array}$ & $\begin{array}{l}\text { Очікування послуги } \\
\text { портьє протягом } 2 \text { хв }\end{array}$ & $\begin{array}{l}\text { Очікування послуги } \\
\text { портьє протягом } 3 \text { хв }\end{array}$ & $\begin{array}{l}\text { Очікування послуги } \\
\text { портьє більше } 5 \text { хв }\end{array}$ \\
\hline $\begin{array}{l}\text { Знайомство із сучасним } \\
\text { електронним } \\
\text { обладнанням у номері }\end{array}$ & $\begin{array}{l}\text { Детальне знайомство } 3 \\
\text { роботою електронного } \\
\text { обладнання }\end{array}$ & $\begin{array}{l}\text { Поверхневе знайомство } 3 \\
\text { роботою сучасного } \\
\text { обладнання }\end{array}$ & $\begin{array}{l}\text { Відсутнє знайомство із } \\
\text { сучасним обладнанням }\end{array}$ \\
\hline $\begin{array}{l}\text { Знайомство з роботою } \\
\text { зручностей у номері }\end{array}$ & $\begin{array}{l}\text { Детальне знайомство } 3 \\
\text { роботою зручностей }\end{array}$ & $\begin{array}{l}\text { Загальні відомості щодо } \\
\text { роботи зручностей }\end{array}$ & $\begin{array}{l}\text { Відсутнє знайомство } 3 \\
\text { роботою зручностей }\end{array}$ \\
\hline $\begin{array}{l}\text { Електронний ключ- } \\
\text { картка }\end{array}$ & $\begin{array}{l}\text { Видається після } \\
\text { реєстрації. Якщо } \\
\text { втрачено, то видається } \\
\text { новий }\end{array}$ & $\begin{array}{l}\text { Видається після реєстрації. } \\
\text { Якщо втрачено, видача } \\
\text { нового є платною }\end{array}$ & $\begin{array}{l}\text { Видається тільки один } \\
\text { ключ-картка }\end{array}$ \\
\hline Звичайний ключ & Відсутня & $\begin{array}{l}\text { Видається у випадку } \\
\text { втрати ключа-карточки }\end{array}$ & $\begin{array}{l}\text { Видається як єдиний } \\
\text { ключ від номеру }\end{array}$ \\
\hline Кваліфікація & Вища професійна освіта & Середня професійна освіта & $\begin{array}{l}\text { Відсутня професійна } \\
\text { освіта }\end{array}$ \\
\hline $\begin{array}{l}\text { Дотримання норм } \\
\text { професійної етики }\end{array}$ & $\begin{array}{l}\text { Дотримання норм } \\
\text { професійної етики на } \\
\text { всіх етапах роботи }\end{array}$ & $\begin{array}{l}\text { Недотримання } \\
\text { професійної етики на } \\
\text { деяких етапах роботи }\end{array}$ & $\begin{array}{l}\text { Відсутнє дотримання } \\
\text { норм професійної етики }\end{array}$ \\
\hline $\begin{array}{l}\text { Знання та виконання } \\
\text { посадових інструкцій }\end{array}$ & $\begin{array}{l}\text { Посадові інструкції } \\
\text { виконуються повністю }\end{array}$ & $\begin{array}{l}\text { Інколи посадові інструкції } \\
\text { порушуються }\end{array}$ & $\begin{array}{l}\text { Посадових інструкцій не } \\
\text { дотримуються }\end{array}$ \\
\hline
\end{tabular}

Комплексний метод оцінки якості продукції і послуг, який в теперішній час широко використовується в сучасних наукових дослідженнях, полягає у вираженні оцінки рівня якості одним числом, яке отримаємо в результаті об'єднання використаних одиничних показників якості в один комплексний показник. Для об'єднання одиничних показників й отримання об’єднаної загальної оцінки, використано середньозважену арифметичну (аддитивну) величину, яка найбільш широко використовується у кваліметрії. Вимірювання окремих показників якості $P_{i}$ або якості загалом завершується визначенням відносного показника оцінки якості:

$$
\mathrm{K}_{i j}=f\left(P_{i j}, P_{i j}^{\text {баз }}\right),
$$

де $P_{i j}^{\text {баз }}$ - базовий показник якості (3 бали), прийнятий нами за еталон, відповідно до вимог нормативної документації на послуги приймання i 
розміщення в готельних закладах. Кожна властивість якості визначається двома числовими параметрами: відносним показником якості $K_{i j}$ і вагомістю $m_{i j}$ цієї властивості. Сума вагомостей властивостей одного рівня $\epsilon$ величиною постійною:

$$
\sum_{i=1}^{n} m_{i j}=\text { const. }
$$

Коефіцієнт вагомості показника якості певної властивості, під час комплексної оцінки якості, $є$ кількісною характеристикою його значущості серед інших показників якості. Сума коефіцієнтів вагомості в межах однієї групи показників якості послуг, а також сума коефіцієнтів вагомості всіх виділених груп показників якості послуг, приймається рівною одиниці:

$$
\sum_{i=1}^{n} m_{i K}=1 ; \sum_{K=1}^{t} M_{K}=1 \text {. }
$$

Математична модель комплексного показника якості повинна відображати ієрархічну структуру рівнів властивостей, які враховуються i характеризують якість послуг бронювання і розміщення в готелі. Враховуючи, що у нашому випадку показники якості послуг утворюють чотирьохрівневу структуру, то математична модель комплексного показника, як середньозважена арифметична величина, має такий вигляд:

$$
K_{0}=\sum_{k=1}^{t} M_{k} \times \sum_{j=1}^{n_{k}} M_{j k} \times \sum_{i=1}^{n_{j k}} M_{i j k} \times \sum_{z=1}^{n_{i j k}} m_{z i j k} \times K_{z i j k},
$$

де $t$ - кількість комплексних показників якості 1-го рівня; $n_{k}-$ кількість показників 2-го рівня в $k$-тій групі показників; $n_{i j k}$ - кількість одиничних показників якості, що входять до $i j k$-тої підгрупи; $M_{k}, M_{j k}, M_{i j k}, m_{z i j k}-$ коефіцієнти вагомості показників, відповідно 1-го, 2-го, 3-го і 4-го рівнів; $K_{z i j k}-$ коефіцієнт оцінки одиничних показників якості щодо еталону, який становить 3 бали [13, с. 109].

У таблиці 3 наведено коефіцієнти вагомості показників, абсолютні значення одиничних показників й оцінка якості послуг служби приймання $\mathrm{i}$ розміщення.

Коефіцієнти вагомості були призначені за ступенем важливості для гостей. Для будь-якої групи показників сума коефіцієнтів вагомості дорівнює одиниці:

$$
\sum_{k=1}^{t} M_{k} \times \sum_{j=1}^{n_{k}} M_{j k} \times \sum_{i=1}^{n_{j k}} M_{i j k} \times \sum_{z=1}^{n_{i j k}} m_{z i j k}=1
$$

Розрахунок одиничних показників якості $K_{z i j k}$ виконується за формулою:

$$
K_{z i j k}=\frac{P_{z i j k}}{B},
$$

де $P_{z i j k}$ - абсолютне значення показника якості послуги об’єкту дослідження; $B$ - максимальна кількість балів за шкалою вимірювання.

Отримані дані свідчать, що найвищу оцінку отримали такі види послуг на етапі бронювання і розміщення, як розрахунок кредитною карткою, що значно прискорює процес розміщення в готелі, і тривалість реєстрації, яка не перевищує 10 хвилин, що свідчить про оперативну й злагоджену роботу персоналу готелю. Високу оцінку отримала така послуга як «електронний ключ-картка», завдяки зручності його зберігання і використання. Гості готелю високо оцінили професіоналізм обслуговуючого персоналу, його кваліфікацію, тактовність, уважність і доброзичливість. Найнижчу оцінку отримали такі послуги, як «тривалість очікування портьє» для супроводу до номеру i 
допомоги з багажем більше 3 хвилин, а інколи й більше 5 хвилин. У зв'язку 3 наданням послуг попередньому гостю, він не завжди знайомить гостя зі зручностями номеру, тому що поспішає до зустрічі нового гостя.

Табличя 3

Оцінки показників якості служби приймання і розміщення в готелі «Gagarinn» та їхня вагомість

\begin{tabular}{|c|c|c|c|c|c|c|c|c|c|}
\hline \multicolumn{8}{|c|}{ Групи й підгрупи показників якості й коефіцієнтів вагомості } & \multirow[b]{2}{*}{ 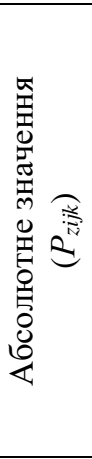 } & \multirow[b]{2}{*}{ 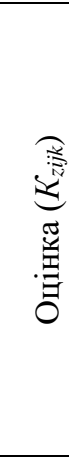 } \\
\hline 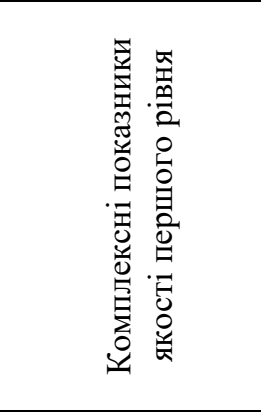 & 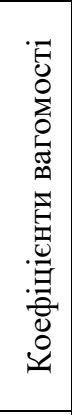 & 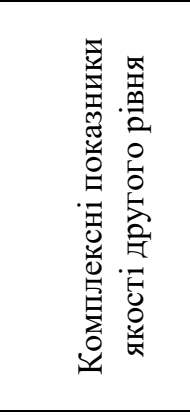 & 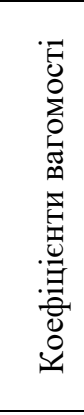 & 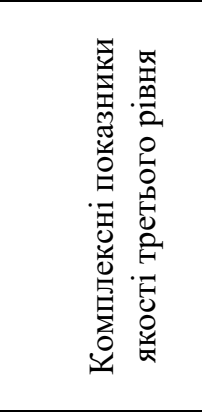 & 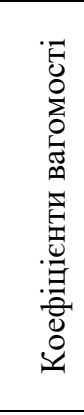 & 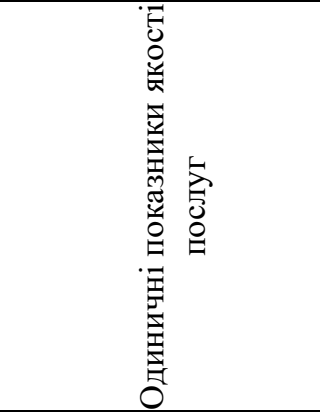 & 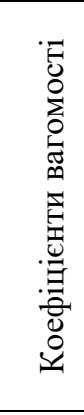 & & \\
\hline \multirow{3}{*}{$\begin{array}{l}\text { Відповідність } \\
\text { ціновому } \\
\text { призначенню }\end{array}$} & \multirow{3}{*}{0,5} & \multirow{3}{*}{$\begin{array}{l}\text { Статус } \\
\text { гостя }\end{array}$} & \multirow{3}{*}{1} & \multirow{3}{*}{$\begin{array}{l}\text { Види } \\
\text { обслугову- } \\
\text { вання }\end{array}$} & \multirow{3}{*}{1} & $\begin{array}{l}\text { Оплата кредитною } \\
\text { карткою }\end{array}$ & 0,4 & 3 & 1 \\
\hline & & & & & & Оплата готівкою & 0,35 & 2 & 0,66 \\
\hline & & & & & & $\begin{array}{l}\text { Оплата через } \\
\text { рахунковий рахунок }\end{array}$ & 0,25 & 2 & 0,66 \\
\hline \multirow{8}{*}{$\begin{array}{l}\text { Дотримання } \\
\text { стандартів } \\
\text { обслуговування }\end{array}$} & \multirow{8}{*}{0,3} & \multirow{6}{*}{$\begin{array}{l}\text { Точність і } \\
\text { своєчас- } \\
\text { ність } \\
\text { надання } \\
\text { послуги }\end{array}$} & \multirow{6}{*}{0,55} & \multirow{6}{*}{$\begin{array}{l}\text { Точність і } \\
\text { своєчасність } \\
\text { надання } \\
\text { послуги }\end{array}$} & \multirow{6}{*}{0,55} & $\begin{array}{l}\text { Тривалість } \\
\text { перевірки наявності } \\
\text { заявки на } \\
\text { бронювання }\end{array}$ & 0,1 & 2 & 0,66 \\
\hline & & & & & & $\begin{array}{l}\text { Тривалість } \\
\text { реєстрації }\end{array}$ & 0,3 & 3 & 1 \\
\hline & & & & & & $\begin{array}{l}\text { Тривалість } \\
\text { ознайомлення } 3 \\
\text { правилами }\end{array}$ & 0,1 & 2 & 0,66 \\
\hline & & & & & & $\begin{array}{l}\text { Тривалість } \\
\text { очікування портьє }\end{array}$ & 0,2 & 1 & 0,33 \\
\hline & & & & & & $\begin{array}{l}\text { Тривалість } \\
\text { знайомства } 3 \\
\text { обладнанням } \\
\text { номеру }\end{array}$ & 0,15 & 2 & 0,66 \\
\hline & & & & & & $\begin{array}{l}\text { Тривалість } \\
\text { знайомства із } \\
\text { зручностями у } \\
\text { номері }\end{array}$ & 0,15 & 1 & 0,33 \\
\hline & & \multirow{2}{*}{$\begin{array}{l}\text { Видача } \\
\text { ключа }\end{array}$} & \multirow[t]{2}{*}{0,45} & \multirow{2}{*}{$\begin{array}{l}\text { Видача } \\
\text { ключа }\end{array}$} & \multirow[t]{2}{*}{0,45} & $\begin{array}{l}\text { Електронний ключ- } \\
\text { картка }\end{array}$ & 0,7 & 3 & 1 \\
\hline & & & & & & Звичайний ключ & 0,3 & 1 & 0,33 \\
\hline \multirow{3}{*}{$\begin{array}{l}\text { Професіоналізм } \\
\text { персоналу }\end{array}$} & \multirow{3}{*}{0,2} & \multirow{3}{*}{$\begin{array}{l}\text { Культура } \\
\text { обслугову- } \\
\text { вання }\end{array}$} & \multirow{3}{*}{1} & \multirow{3}{*}{$\begin{array}{l}\text { Культура } \\
\text { обслугову- } \\
\text { вання }\end{array}$} & \multirow{3}{*}{1} & $\begin{array}{l}\text { Кваліфікація } \\
\text { персоналу }\end{array}$ & 0,6 & 3 & 1 \\
\hline & & & & & & $\begin{array}{l}\text { Знання та } \\
\text { виконання } \\
\text { посадових } \\
\text { інструкцій }\end{array}$ & 0,2 & 2 & 0,66 \\
\hline & & & & & & $\begin{array}{l}\text { Дотримання норм } \\
\text { професійної етики }\end{array}$ & 0,2 & 2 & 0,66 \\
\hline
\end{tabular}

\section{Джерело: складено авторами за результатами досліджень}

Результати оцінки якості послуг за груповими ознаками становлять: відповідність цільовому призначенню - 0,796, дотримання стандарту обслуговування - 0,718, професіоналізм персоналу й культура 
обслуговування - 0,864. Тобто, гості закладу розміщення найбільше цінують професіоналізм і культуру обслуговування, потім зручність розрахунку й стандарт обслуговування. Комплексна оцінка якості обслуговування гостей в закладі розміщення становить 0,65 , що за шкалою бажаності Харінгтона відповідає оцінці «добре», тому що потрапляє в інтервал $0,8 \ldots . .0,63$. Безрозмірна шкала Харрінгтона встановлює відповідність між фізичними й психологічними показниками. Під фізичними показниками розуміють будь-які можливі значення показників якості властивостей, під психологічними суб'єктивну оцінку бажаності або переваги того чи іншого значення показника якості обслуговування.

Висновки. Авторами розглянуто проблеми стандартизації послуг в індустрії гостинності й зроблено висновки про те, що якість готельноресторанного продукту залежить, насамперед, від створення стандартів якості на підприємстві щодо міжнародних вимог та обов'язкове їхнє дотримання. Проведений аналіз якості послуг служби бронювання і розміщення за методом комплексного дослідження, запропонованим Топольник В.Г., у готелі «Gagarinn», дозволив отримати об'єктивну оцінку роботи персоналу 3 гостями i культурою обслуговування на етапі реєстрації, знайомства 3 оснащенням номеру, роботою зручностей. Отримані нами результати свідчать, що якість наданих послуг на етапі бронювання і розміщення відбувається на досить високому рівні. Співробітники служби приймання i розміщення виконують свої обов'язки на високому професійному рівні, додержуються професійної етики, ввічливі, уважні й доброзичливі. Найбільш слабким місцем виявилось дотримання стандартів обслуговування, у зв'язку 3 несвоєчасним виконанням своїх обов'язків портьє під час завантаженості готелю у «високий сезон» або під час заїзду в готель учасників конференцій, з'їздів, симпозіумів тощо. У таких випадках необхідно передбачити розподілення обов'язків портьє між двома, а інколи й трьома співробітниками закладу.

\section{Список використаних джерел}

1. Подлепіна П.О. Конкурентоспроможність як чинник підвищення ефективності функціонування готельних підприємств. Вісник Харківського національного університету ім. В.Н. Каразіна. Серія «Міжнародні відносини. Економіка. Країнознавство. Туризм». 2013. № 1042. C. $128-131$.

2. Охота В.I. Шляхи підвищення конкурентоспроможності підприємств готельної індустрії. Інвестииії: практика та досвід. 2017. № 5. С. 46-49.

3. Ивченко Л.А., Редько В.Е. Квалиметрические методы оценки привлекательности гостиничных услуг. Вісник ДІТБ. Серія: Економіка, організація та управління підприємствами туристичної індустрї та туристичної галузі в иілому. 2013. № 17. С. 275-282.

4. Сиволап Л.А. Конкурентоспроможності підприємства в сучасних умовах господарювання. Східна Європа: економіка, бізнес та управління. 2017. 
Вип. 6 (11). С. 395-397.

5. Батченко Л.В., Стариченко Т.В. Концептуальний підхід до конкурентоспроможності готельних підприємств України. Ефективна економіка. 2018. № 9. URL: http://www.economy.nayka.com.ua/pdf/9_2018/9.pdf. (дата звернення: 16.11.2021).

6. Ye F., Xia Q., Zhang M., Zhan Y., Li Y. Harvesting Online Reviews to Identify the Competitor Set in a Service Business: Evidence from the Hotel Industry. Journal of Service Research. 2020. URL: https://journals.sagepub.com/doi/full/ 10.1177/1094670520975143. DOI: https://doi.org/10.1177/1094670520975143 (дата звернення: 16.11.2021).

7. Zelga K. The importance of competition and enterprise competitiveness. World Scientific News. 2017. № 72. P. 301-306.

8. ДСТУ ISO 9000-2015. Система управління якістю. Основні положення та словник термінів. [Чинний від 2016-07-01]. Вид. офіц. Київ: Держстандарт України, 2016. 45 с.

9. ДСТУ ISO 9001:2015. Системи управління якістю. Вимоги. [Чинний від 2016-07-01]. Вид. офіц. Київ : Держстандарт України, 2016. 22 с.

10. ДСТУ 3410-96 Система сертифікації УкрСЕПРО. Основні положення. [Чинний від 1997-04-01]. Вид. офіц. Київ: Держстандарт України, 1997. $31 \mathrm{c}$.

11. ДСТУ 4268:2003. Послуги туристичні. Засоби розміщування. Загальні вимоги. [Чинний від 2004-07-01]. Вид. офіц. Київ: Держстандарт України, 2003. 14 с.

12. Топольник В.Г., Ратушный А.С. Квалиметрия в ресторанном хозяйстве : монография. Донецк: ДонНУЭТ, 2008. 243 с.

13. Топольник В.Г. К вопросу методики количественной оценки качества СПиР гостиничного комплекса. Актуальные вопросы гостиничноресторанного бизнеса: материалы Международной научно-практической интернет-конференции преподавателей и молодых ученых (г. Донецк 20-21 ноября 2015 г.). Донецк: ДонНУЭТ, 2015. С. 108-110.

\section{References}

1. Podlepina, P.O. (2013). Konkurentospromozhnistj jak chynnyk pidvyshhennja efektyvnosti funkcionuvannja ghoteljnykh pidpryjemstv [Competitiveness as a Factor for Increasing the Efficiency of Hotel Enterprises Operation]. Visnyk Kharkivskoho natsionalnoho universytetu im. V.N. Karazina. Seriia «Mizhnarodni vidnosyny. Ekonomika. Krainoznavstvo. Turyzm» Bulletin of Kharkiv National University. V.N. Karazina. Series «International Relations. Economy. Local lore. Tourism», 1042, 128-131 [in Ukrainian].

2. Okhota, V.I. (2017). Shlyahi pidvischennya konkurentospromozhnosti pidpriemstv gotelnoyi industriyi [Ways to increase competitiveness of hotel industry enterprises]. Investytsiyi: praktyka ta dosvid - Investments: practice and experience, 5, 46-49 [in Ukrainian]. 
3. Ivchenko, L.A., \& Redko, V.Ye. (2013). Kvalimetricheskiye metody otsenky privlekatelnosti gostinichnykh uslug [Qualitative methods of assessing the attractiveness of hotel services]. Visnyk DITB. Seriia: Ekonomika, orhanizatsiia ta upravlinnia pidpryiemstvamy turystychnoi industrii ta turystychnoi haluzi v tsilomu Bulletin of the DITB. Series: Economics, organization and management of enterprises in the tourism industry and the tourism industry in general, 17, 275-286 [in Russian].

4. Sivolap L.A. (2017). Konkurentospromozhnosti pidpriєmstva v suchasnih umovah gospodaryuvannya [Competitiveness of the Enterprise in Modern Conditions of Business]. Skhidna Yevropa: ekonomika, biznes ta upravlinnia - Eastern Europe: Economy, Business and Management, 6 (11), 395-397 [in Ukrainian].

5. Batchenko, L.V., \& Starychenko, T.V. (2018). Kontseptualniy pidkhid do konkurentospromozhnosti hotelnikh pidpriyemstv Ukrayini [Conceptual approach of competitiveness of hotel business in Ukraine]. Efektyvna ekonomika - Efficient economy, 9. Retrieved from: http://www.economy.nayka.com.ua/?op=1\&z=6721 [in Ukrainian].

6. Ye, F., Xia, Q., Zhang, M., Zhan, Y., \& Li, Y. (2020). Harvesting Online Reviews to Identify the Competitor Set in a Service Business: Evidence from the Hotel Industry. Journal of Service Research. Retrieved from: https://journals.sagepub.com/doi/full/10.1177/1094670520975143. DOI: https://doi. org/10.1177/1094670520975143 [in English].

7. Zelga, K. (2017). The importance of competition and enterprise competitiveness. World Scientific News, 72, 301-306 [in English].

8. Systema upravlinnia yakistiu. Osnovni polozhennia ta slovnyk terminiv [Quality management systems. Fundamentals and vocabulary]. (2015). DSTU ISO 9000:2015 from 1 $1^{\text {st }}$ July, 2016. Kyiv: Derzhstandart Ukraine [in Ukrainian].

9. Sistemi upravlinnya yakistyu. Vimogi [Quality management systems. Requirements]. (2009). DSTU ISO 9001:2015 from $1^{\text {st }}$ July, 2016. Kyiv: Derzhstandart Ukraine [in Ukrainian].

10. Systema sertyfikatsii UkrSEPRO. Osnovni polozhennia [UkrSEPRO certification system. Substantive provisions]. (1997). DSTU 9001:2015 from $1^{\text {st }}$ April 1997. Kyiv: Derzhstandart Ukraine [in Ukrainian].

11. Posluhy turystychni. Zasoby rozmishchuvannia. Zahalni vymohy [Tourist services. Accommodation facilities. general requirements]. (2003). DSTU 4268:2003 from $1^{\text {st }}$ July 2004. Kyiv: Derzhstandart Ukraine [in Ukrainian].

12. Topolnik, V.G., \& Ratushnyiy, A.S. (2008). Kvalimetriya v restorannom hozyaystve [Qualimetry in the restaurant industry]. Donetsk: DonNUET [in Russian].

13. Topolnik, V.G. (2015). K voprosu metodiki kolichestvennoy otsenki kachestva SPiR gostinichnogo kompleksa [On the question of the methodology for quantitative assessment of the quality of the Reception and Accommodation Service of the hotel complex]. Mezhdunarodnaya nauchno-prakticheskaya internetkonferentsiya prepodavateley $i$ molodyih uchenyih - International scientific and practical Internet conference for teachers and young scientists. (pp. 108-110). Donetsk: DonNUET [in Russian]. 


\section{Відомості про авторів}

Д'ЯКОНОВА Анджела Костянтинівна - доктор технічних наук, професор кафедри готельно-ресторанного бізнесу, Одеський національний технологічний університет (65039, м. Одеса, вул. Канатна, 112 , e-mail: angela1943@ukr.net).

ТІТОМИР Людмила Анатоліївна - кандидат технічних наук, доцент кафедри готельно-ресторанного бізнесу, Одеський національний технологічний університет (65039, м. Одеса, вул. Канатна, 112, e-mail: mila_titomir@ukr.net).

ХАЛІЛОВА-ЧУВАСВА Юлія Олександрівна - кандидат політології, доцент кафедри готельно-ресторанного бізнесу, Одеський національний технологічний університет (65039, м. Одеса, вул. Канатна, 112, e-mail: julik6446@gmail.com).

КОРОТИЧ Олена Миколаївна - старший викладач кафедри готельноресторанного бізнесу, Одеський національний технологічний університет (65039, м. Одеса, вул. Канатна, 112, e-mail: kelena1811@gmail.com).

DYAKONOVA Andzhela - Doctor of Technical Sciences, Professor of the Department of Hotel and Restaurant Business, Odessa National Technological University (65039, Odessa, 112, Kanatna Str., e-mail: angela1943@ukr.net).

TITOMYR Liudmyla - Candidate of Technical Sciences, Associate Professor of the Department of Hotel and Restaurant Business, Odessa National Technological University (65039, Odessa, 112, Kanatna Str., e-mail: mila_titomir@ukr.net).

KHALILOVA-CHUVAIEVA Yuliia - Candidate of Politology, Associate Professor of the Department of Hotel and Restaurant Business, Odessa National Technological University (65039, Odessa, 112, Kanatna Str., e-mail: julik6446@gmail.com).

KOROTYCH Olena - Senior Lecturer of the Department of Hotel and Restaurant Business, Odessa National Technological University (65039, Odessa, 112, Kanatna Str., e-mail: kelena1811@gmail.com).

ДъЯКОНОВА Анджела Константиновна - доктор технических наук, профессор кафедры гостинично-ресторанного бизнеса, Одесский национальный технологический университет (65039, г. Одесса, ул. Канатная, 112, e-mail: angela1943@ukr.net).

ТИТОМИР Людмила Анатольевна - кандидат технических наук, доцент кафедры гостинично-ресторанного бизнеса, Одесский национальный технологический университет (65039, г. Одесса, ул. Канатная, 112, e-mail: mila_titomir@ukr.net).

ХАЛИЛОВА-ЧУВАЕВА Юлия Александровна - кандидат политологии, доцент кафедры гостинично-ресторанного бизнеса, Одесский национальный технологический университет (65039, г. Одесса, ул. Канатная, 112, e-mail: julik6446@gmail.com).

КОРОТЫЧ Елена Николаевна - старший преподаватель кафедры гостинично-ресторанного бизнеса, Одесский национальный технологический университет (65039, г. Одесса, ул. Канатная, 112, e-mail: kelena1811@gmail.com). 